\title{
Mechanical Evaluation and Minerals Phases Identification of Fine and Coarse Okelele Block Clay Composites for Furnace Lining Application
}

\author{
Yusuf Olanrewaju Saheed, Mufutau Abiodun Salawu*, Aderemi Babatunde Alabi \\ Department of Physics, University of Ilorin, Ilorin, Nigeria
}

\begin{abstract}
The suitability of fine and coarse Okelele clays as refractory raw materials for furnace lining application was investigated. The clay samples were crushed and pounded with a mortar and pestle to a particle size of 20 microns. $230 \mathrm{~g}$ each of fine clay was mixed with 50 mls of water inside a bowl and stirred thoroughly to form homogenous plastic paste. $10 \mathrm{~g}, 15 \mathrm{~g}, 25 \mathrm{~g}, 35 \mathrm{~g}$ and $45 \mathrm{~g}$ of coarse clay were added respectively to the 230 $\mathrm{g}$ of homogenous fine clay paste in different container. The fine and coarse clays composites weighing $240 \mathrm{~g}, 245 \mathrm{~g}, 255 \mathrm{~g}, 265 \mathrm{~g}$ and $275 \mathrm{~g}$ were respectively put in a mold of dimension $3 \times 5 \times 6 \mathrm{~cm}$ and air dried for 7 days. The samples were fired at temperature of $1200{ }^{\circ} \mathrm{C}$ for five hours using Carbolite Furnace. After cooling, the fine and coarse clay composites of $240 \mathrm{~g}$ and $245 \mathrm{~g}$ were broken by the heat and composites blocks $255 \mathrm{~g}$, $265 \mathrm{~g}$ and $275 \mathrm{~g}$ were hardened and remove for compressive test analysis. The fine and coarse clays were characterized using X-ray Diffractometer PW 1830 for minerals phases' identification. The result of XRD shows that the clay was majorly composed of Quartz and Kaolinite with the traces of other minerals such as Smectile, Illite/Mica, Albite, Jarosite, Gypsum and Pyrite. The Kaolinite contains aluminum silicate $\left(\mathrm{Al}_{2} \mathrm{O}_{3} \cdot 2 \mathrm{SiO}{ }_{2}\right)$ and Quartz has the silicon and oxygen atoms. The compressive strength test result judged the $275 \mathrm{~g}$ fire block of clays composite the best with the maximum force breaks of $7652 \mathrm{~N}$ with deflection of $3.734 \mathrm{~mm}$ and Young Modulus of $212 \mathrm{~N} / \mathrm{mm}^{2}$ for the time to failure of 22 seconds. The results proved that Okelele clays are suitable as refractory material for furnace lining application.
\end{abstract}

\section{DOI:10.46481/jnsps.2022.252}

Keywords: Okelele clays, Kaolinite, Quartz, Refractory materials

Article History :

Received: 13 June 2021

Received in revised form: 14 October 2021

Accepted for publication: 19 October 2021

Published: 28 February 2022

(c)2022 Journal of the Nigerian Society of Physical Sciences. All rights reserved. Communicated by: S. J. Adebiyi

\section{Introduction}

Nigeria is rich with abundant mineral resources but these resources have not been sufficiently explored and used. Clay is a naturally occurring material composed of layered structures

\footnotetext{
${ }^{*}$ Corresponding author tel. no:

Email address: salawu.ma@unilorin.edu.ng; abideen2004@gmail.com (Mufutau Abiodun Salawu )
}

of fine-grained minerals which reveal the property of plasticity at appropriate water content and permanently hard when fired [1]. Clay as a mineral that consist of silica $\left(\mathrm{SiO}_{2}\right)$, Alumina $\left(\mathrm{Al}_{2} \mathrm{O}_{3}\right)$, water $\left(\mathrm{H}_{2} \mathrm{O}\right)$, and other impurities are aluminosilicate, mostly answerable for its thermal property of refractoriness which applicable in the manufacturing of several refractory products. It is earthen and soil with intricate inorganic blend, whose structure diverges and generally depends on the environmental and geographical position [2]. 
High demand for refractory materials for Furnace building and other related high temperature processes is enormous. Nigeria spends more than 2.27 billion naira yearly on the importation of refractories for industrial application [3]. The application of clay composites as a refractory material depends severally on its thermal property of refractoriness, chemical composition, mechanical and physical properties [2], [5-13]. Refractory materials are inorganic materials containing the mixtures of oxides obtained from naturally occurring minerals capable of withstanding very high temperature conditions without cracking, deforming, softening or change in composition [3]. The good characteristic of a refractory is to provide basic thermal properties, support winding (electric resistance) and be able to hold solid or liquid metals without entering into any undesirable chemical reaction with them. Thus refractory materials are characterized by the ability to withstand the heat, chemical attack, abrasion, impact, and shock caused by thermal stresses.

The clays used for furnace linings in metallurgical industries are classified as refractory clays. However, the degree of refractoriness and plasticity of any clay material is often influenced by the amount of the impurities contained in them [13]. The mechanical properties of different particle sizes of some impurities for some specific application had been investigated [14]. Chanchanga, Bida, Suleja and Zungeru clays deposits have better refractory and physical properties when compared with imported ones [3]. Some local clay deposits in other part of Nigeria have also been investigated with good results. Some of the clay deposits investigated for refractory application includes but not limited to Dukku clay deposit in Gombe State, Onibode, Ibamajo, Ijoko in Ogun State and Are in Ekiti State [15]. The characterization of Otukpo clay in Benue State was also reported [16].

The economic circumstance in Nigeria as at today has necessitated for the inward sourcing of locally available raw materials across the country for domestic and industrial applications. Due to the aforementioned economic needs and the fact that the Okelele clay deposit in Ilorin, Kwara State is only used for local pottery by old women living around the area and building bricks by local bricklayer. The minerals phases' identification and refractory properties of this particular clay deposit needs to be investigated.

\section{Materials and Method}

The fine and coarse clay samples were collected from a deposit in Okelele, Ilorin East local government area of Kwara state. The Molding iron bar, Mortar and pistol, Electronic weighing balance, HT 4/28 Carbolite Gero Muffle Furnace Machine located at Geology Department, University of Ilorin, (0-3000 $\left.{ }^{\circ} \mathrm{C}\right)$, XFS300 Testometric compression test machine located at Agricultural Biotechnology Laboratory, Department of Biotechnology engineering, University of Ilorin and PW 1830 X-ray Diffractometer located at the Department of Geology, University of Ibadan were used in this work. The clay samples were crushed and pounded with a mortar and pestle to a particle size of 20 microns. $230 \mathrm{~g}$ each of fine clay was mixed with $50 \mathrm{mls}$

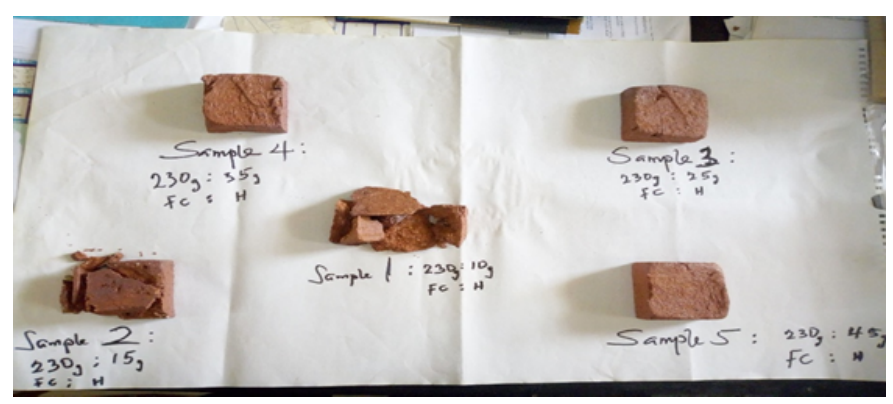

Figure 1. Shows the broken and unbroken Fired Block of Clays after firing

of water inside a bowl and stirred thoroughly to form homogenous plastic paste. $10 \mathrm{~g}, 15 \mathrm{~g}, 25 \mathrm{~g}, 35 \mathrm{~g}$ and $45 \mathrm{~g}$ of coarse clay were added respectively to the $230 \mathrm{~g}$ of homogenous fine clay paste. The fine and coarse clays composites weighing 240 g, $245 \mathrm{~g}, 255 \mathrm{~g}, 265 \mathrm{~g}$ and $275 \mathrm{~g}$ were respectively put in a mold of dimension $3 \times 5 \times 6 \mathrm{~cm}$ and air dried for 7 days. The samples were fired at temperature of $1200{ }^{\circ} \mathrm{C}$ for 12 hours using HT 4/28 Carbolite Gero Muffle Furnace $\left(0-3000^{\circ} \mathrm{C}\right)$. After cooling, the fine and coarse clay composites of $240 \mathrm{~g}$ and $245 \mathrm{~g}$ were broken by the heat and composites $255 \mathrm{~g}, 265 \mathrm{~g}$ and $275 \mathrm{~g}$ were hardened and sound like a glass when tapped. Figure 1 shows the fabricated broken and unbroken fired block of clays after firing.

\subsection{X-ray Diffractometer (XRD) Analysis}

XRD was used to identify the phase of minerals constituents of the clays. The fine and coarse clays were separately crushed and milled to fine particles and put in test tubes. The samples were subjected to X-ray using the Philips PW 1830 X-ray diffractometer with a cu-anode at the "University of Ibadan" Ibadan, Oyo State. After the X-ray characterization of the samples, mineral peaks were identified using XPert High Score plus Software. The background and peak positions were identified and based on the peak positions and intensities; a search-match routine was performed.

\subsection{Compression Test}

The unbroken fired block of clays $(255 \mathrm{~g}, 265 \mathrm{~g}$ and $275 \mathrm{~g}$ ) were subjected to mechanical compression test at the Civil Engineering Laboratory of the University of Ilorin, Ilorin Kwara State, to show how these materials deform (elongate, compress, twist) or break as a function of applied load, time, temperature and other conditions. The mechanical test was performed using XFS300 Testometric compression test machine. The capacity of this machine is 10,000 pounds (tension and compression). The samples of the given clay material took a rectangular shape which is unreformed (with no permanent strain or residual stress), or original shape. 


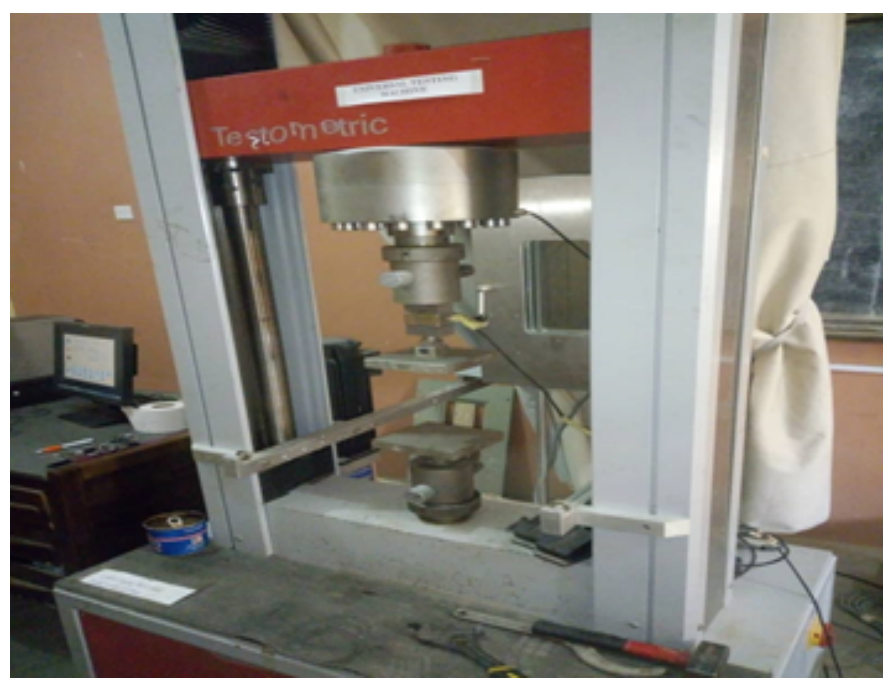

Figure 2. Testometric Compression Test Machine used

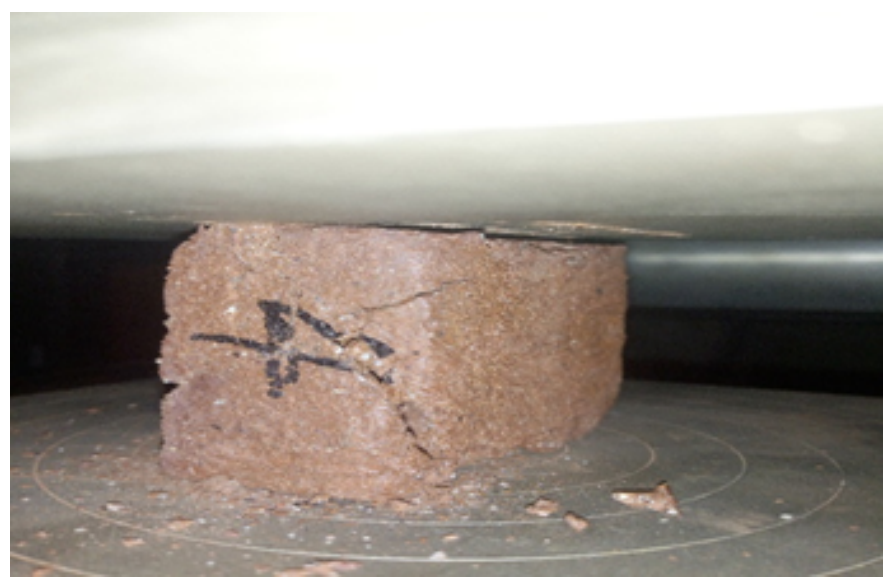

Figure 3. Cracked Block of Clay during Compression Test

\section{Results and Discussion}

Figure 4 and 5 show the XRD patterns of fine and coarse clays. The Debye Scherer equation was employed for the estimation of grain sizes of fine and coarse clays.

$$
\text { Grain size } g=\frac{k \lambda}{\beta \cos \theta}
$$

Where $k$ is the Debye Scherer constant $(0.94)$

$$
\begin{aligned}
& \lambda=1.56 \times 10^{-10} \mathrm{~m}=0.156 \mathrm{~nm} \\
& \beta=(\mathrm{FWHM}) \text { Full width at half maximum (radians) } \\
& \theta=\text { Peak positions (radians) }
\end{aligned}
$$

The estimated grain sizes and mineral constituents of fine and coarse clays are shown in Table 1 and Table 2.

Tables 1 and 2 give the results for the minerals phase identification for the fine and coarse Okelele clays. The Kaolinite and Quartz are dominance in the mineral phase identifications for the fine and coarse Okelele clays composites. Kaolinite which is also called China clay, is the best refractory clay type and will not soften below $1750{ }^{\circ} \mathrm{C}$. Kaolinite clays possessed little plasticity due to their large clay particles. The Kaolinite contains

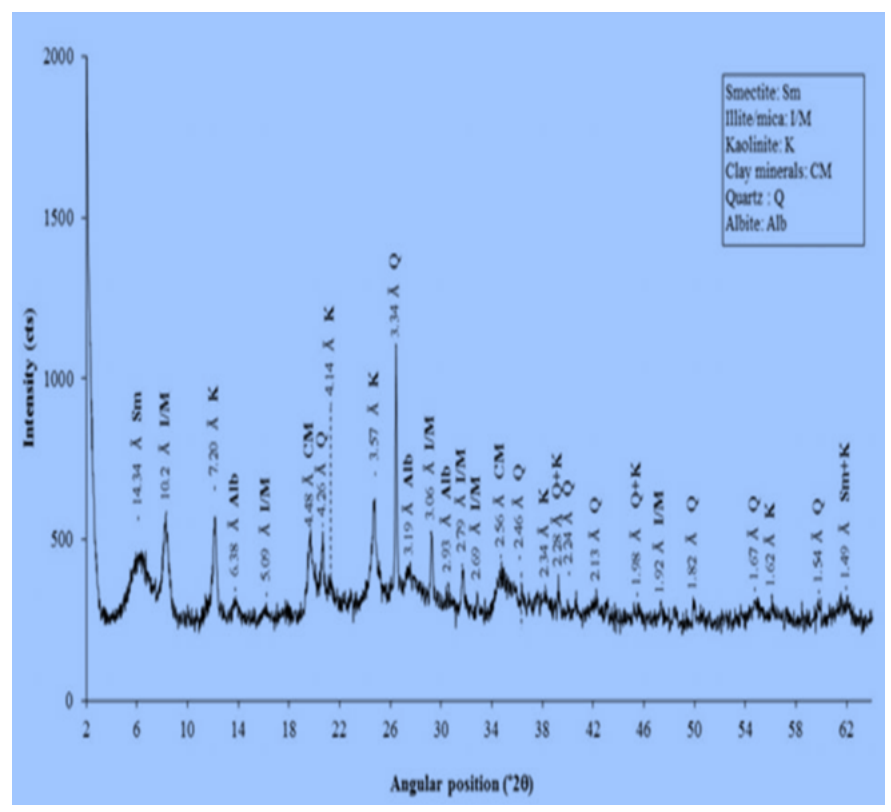

Figure 4. XRD Pattern of Fine Clay

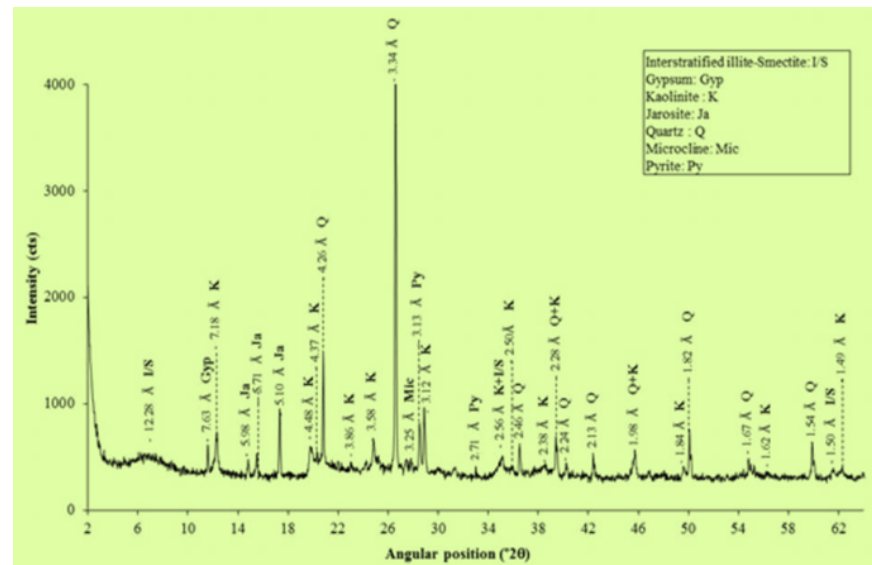

Figure 5. XRD Pattern of coarse Clay

$\mathrm{Al}_{2} \mathrm{O}_{3} \cdot 2 \mathrm{SiO}_{2}$. The pure kaolinite can be found at the site of its parent rock (primary clay) and when it has not been mixed with impurities, its refractoriness is great. The Quartz is a very hard crystalline mineral mostly found in nature contained the silicon and oxygen atoms. Quartz is the most conventional source of silica to be used for refractory production. The refractory made from Silica (Silica refractory bricks) possesses excellent thermal shock resistance at specific temperature range.

The compressive strength test on $255 \mathrm{~g}, 265 \mathrm{~g}$ and $275 \mathrm{~g}$ fire blocks of clay composites were carried out to investigate the load carrying capacity of the fire blocks under compression using compression testing machine. This is important to determine the compressive strength of fire blocks for its suitability as furnace lining. The materials behaviours under a load were determined. The maximum stress a material can withstand over a period under a load (constant or progressive) was determined to a break (rupture) or to a limit. These results are shown in Table 3, 4 and 5 . 
Table 1. Estimated grain sizes and mineral constituents of fine Clay

\begin{tabular}{ccccc}
\hline Peak no. & 2theta (rad) & FWHM & Grain Size $(\mathrm{nm})$ & Constituents \\
\hline 1 & 4.43 & 2.187 & 3.844597803 & Smectile \\
\hline 2 & 8.46 & 5.038 & 1.672251355 & Illite/mica \\
\hline 3 & 12.24 & 7.12 & 1.186799367 & Kaolinite \\
\hline 4 & 13.56 & 5.097 & 1.660000572 & Albite \\
\hline 5 & 15.38 & 3.167 & 2.677013045 & Illite/mica \\
\hline 6 & 19.47 & 5.272 & 1.616958333 & Clay mineral \\
\hline 7 & 20.43 & 2.187 & 3.90360038 & Quartz \\
\hline 8 & 23.46 & 5.038 & 1.703266297 & Kaolinite \\
\hline 9 & 26.24 & 7.12 & 1.211663863 & Kaolinite \\
\hline 10 & 27.56 & 5.097 & 1.697242735 & Quartz \\
\hline 11 & 28.38 & 3.167 & 2.736431091 & Albite \\
\hline 12 & 30.47 & 5.272 & 1.651722605 & Illite/mica \\
\hline 13 & 31.32 & 2.348 & 3.716247528 & Albite \\
\hline 14 & 32.12 & 7.257 & 1.204777898 & Illite/mica \\
\hline 15 & 34.04 & 4.328 & 2.030195653 & Illite/mica \\
\hline 16 & 36.58 & 2.039 & 4.339821991 & Clay mineral \\
\hline 17 & 38.433 & 2.147 & 4.144207588 & Quartz \\
\hline 18 & 40.465 & 5.035 & 1.778423867 & Kaolinite \\
\hline 19 & 42.245 & 7.123 & 1.264497493 & Quartz plus Kaolinite \\
\hline 20 & 46.567 & 5.027 & 1.819527192 & Quartz \\
\hline 21 & 48.382 & 3.164 & 2.91109195 & Quartz \\
\hline 22 & 50.473 & 5.278 & 1.75982879 & Quartz plus Kaolinite \\
\hline 23 & 54.436 & 2.157 & 4.380159907 & Illite/mica \\
\hline 24 & 55.467 & 5.034 & 1.885640471 & Quartz \\
\hline 25 & 60.245 & 7.125 & 1.363317463 & Quartz \\
\hline 26 & 62.562 & 5.077 & 1.936374021 & Kaolinite \\
\hline & & & &
\end{tabular}

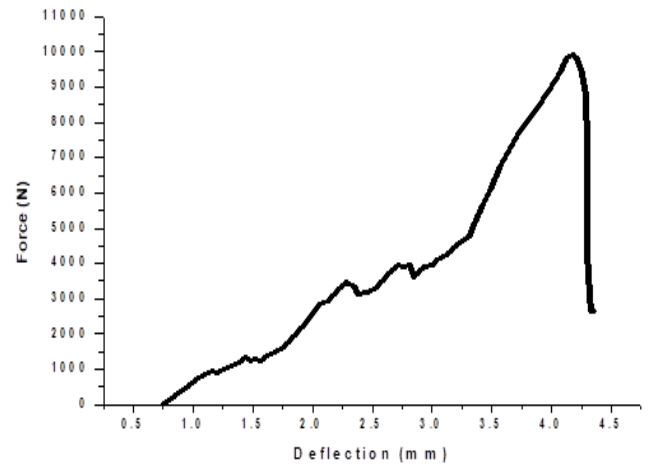

Figure 6. Force $(\mathrm{N})$ against Deflection $(\mathrm{mm})$ of $255 \mathrm{~g}$ fine and coarse fire block clay composites

The $255 \mathrm{~g}$ block has the force break of $2632 \mathrm{~N}$ and deflection break at $4.343 \mathrm{~mm}$. The time to failure is 26.133 seconds for the Young Modulus of $174.476 \mathrm{~N} / \mathrm{mm}^{2}$ among other parameters (Table 3). The $265 \mathrm{~g}$ block has the force break of $1439 \mathrm{~N}$ and deflection breaks at $4.671 \mathrm{~mm}$. The time to failure is 28.1 seconds for the Young Modulus of $94 \mathrm{~N} / \mathrm{mm}^{2}$ (Table 4) while the $275 \mathrm{~g}$ block has the force break of $7652 \mathrm{~N}$ and deflection breaks at $3.734 \mathrm{~mm}$. The time to failure is 22 seconds for the

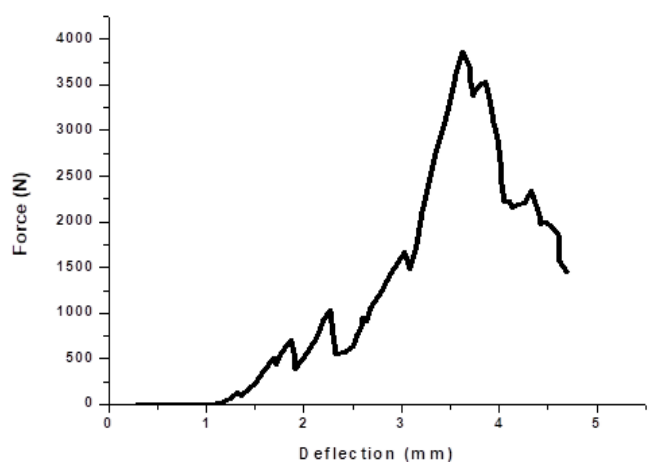

Figure 7. Force $(\mathrm{N})$ against Deflection $(\mathrm{mm})$ of $265 \mathrm{~g}$ fine and coarse fire block of clay composites

maximum Young Modulus of $212 \mathrm{~N} / \mathrm{mm}^{2}$ (Table 5).

Generally, the $275 \mathrm{~g}$ block of fire clays composites requires the maximum break force and has the maximum Young Modulus relatives to blocks $255 \mathrm{~g}$ and $265 \mathrm{~g}$ of clays composites under study. The $275 \mathrm{~g}$ block of fire clay composites will be better for furnace lining application than the $255 \mathrm{~g}$ and $265 \mathrm{~g}$ blocks.

Figures 6, 7 and 8 shows the plots of Force $(\mathrm{N})$ against De- 
Table 2. Estimated grain sizes and mineral constituents of coarse Clay

\begin{tabular}{|c|c|c|c|c|}
\hline Peak no & 2theta (rad) & FWHM & Grain Size $(\mathrm{nm})$ & Constituents \\
\hline 1 & 12.501 & 0.025 & 338.0839019 & Interstratified illite- Smectile \\
\hline 2 & 17.45 & 0.037 & 229.7356597 & Gypsum \\
\hline 3 & 19.86 & 0.128 & 66.63776651 & Kaolinite \\
\hline 4 & 20.941 & 0.136 & 62.82444633 & Jarosite \\
\hline 5 & 21.165 & 0.164 & 52.11724848 & Jarosite \\
\hline 6 & 21.464 & 0.0172 & 497.1759627 & Jarosite \\
\hline 7 & 23.622 & 0.141 & 60.87648083 & Kaolinite \\
\hline 8 & 24.901 & 0.137 & 62.8043888 & Kaolinite \\
\hline 9 & 24.02 & 0.12 & 71.58228586 & Quartz \\
\hline 10 & 26.242 & 0.113 & 76.34585664 & Kaolinite \\
\hline 11 & 28.501 & 0.026 & 333.40756 & Kaolinite \\
\hline 12 & 34.45 & 0.038 & 231.4836125 & Microcline \\
\hline 13 & 35.86 & 0.124 & 71.21558276 & Pyrite \\
\hline 14 & 36.941 & 0.133 & 66.60274151 & Kaolinite \\
\hline 15 & 37.165 & 0.162 & 54.71585907 & Pyrite \\
\hline 16 & 38.464 & 0.017 & 523.4384171 & Kaolinite plus Interstratified illite- Smectile \\
\hline 17 & 39.529 & 0.022 & 405.8083969 & Kaolinite \\
\hline 18 & 40.43 & 0.033 & 271.3138386 & Quartz \\
\hline 19 & 41.821 & 0.122 & 73.72312076 & Kaolinite \\
\hline 20 & 42.937 & 0.134 & 67.37494247 & Quartz plus kaolinite \\
\hline 21 & 45.178 & 0.161 & 56.52152987 & Quartz \\
\hline 22 & 48.426 & 0.170 & 54.14907336 & Quartz \\
\hline 23 & 50.643 & 0.144 & 64.5478197 & Quartz plus kaolinite \\
\hline 24 & 51.936 & 0.13 & 71.88749106 & Quartz \\
\hline 25 & 55.04 & 0.134 & 70.70014627 & Kaolinite \\
\hline 26 & 56.228 & 0.12 & 79.38153044 & Quartz \\
\hline 27 & 60.52 & 0.022 & 442.1458637 & Interstratified illite- Smectile \\
\hline 28 & 62.439 & 0.03 & 327.4856536 & Kaolinite \\
\hline
\end{tabular}

Table 3. Compressibility Analysis of 255g Block of Clay

\begin{tabular}{|c|c|c|c|c|c|c|c|}
\hline $\begin{array}{l}\text { Test } \\
\text { No }\end{array}$ & $\begin{array}{l}\text { Def. @ } \\
\text { Break (mm) }\end{array}$ & $\begin{array}{l}\text { Def. @ } \\
\text { L.O.P. } \\
(\mathrm{mm})\end{array}$ & $\begin{array}{l}\text { Def. @ } \\
\text { Peak } \\
(\mathrm{mm})\end{array}$ & $\begin{array}{l}\text { Def. @ } \\
\text { Yield } \\
(\mathrm{mm})\end{array}$ & $\begin{array}{l}\text { Force @ } \\
\text { Break (N) }\end{array}$ & $\begin{array}{l}\text { Force @ }{ }^{@} \\
\text { L.O.P. (N) }\end{array}$ & $\begin{array}{l}\text { Force @ Peak } \\
(\mathrm{N})\end{array}$ \\
\hline 1 & 4.343 & 2.087 & 4.186 & 2.303 & 2631.700 & 2911.200 & 9924.000 \\
\hline Test & Force & Strain @ & Strain@ & Strain & Strain @ & Stress & Stress \\
\hline No & Yield (N) & Break (\%) & $\begin{array}{l}\text { L.O.P. } \\
(\%)\end{array}$ & $\begin{array}{l}\text { @ Peak } \\
(\%)\end{array}$ & Yield (\%) & $\begin{array}{l}@ \text { Break } \\
\left(\mathrm{N} / \mathrm{mm}^{2}\right)\end{array}$ & $\begin{array}{l}\text { L.O.P. } \\
\left(\mathrm{N} / \mathrm{mm}^{2}\right)\end{array}$ \\
\hline 1 & 3469.000 & 7.896 & 3.795 & 7.611 & 4.187 & 2.056 & 2.274 \\
\hline Test & Stress & Stress & Time to & Time & Youngs & Tangential & Secant Modu- \\
\hline No & $\begin{array}{l}@ \quad \text { Peak } \\
\left(\mathrm{N} / \mathrm{mm}^{2}\right)\end{array}$ & $\begin{array}{l}@ \quad \text { Yield } \\
\left(\mathrm{N} / \mathrm{mm}^{2}\right)\end{array}$ & $\begin{array}{l}\text { Failure } \\
\text { (Secs) }\end{array}$ & $\begin{array}{l}\text { to Peak } \\
\text { (Secs) }\end{array}$ & $\begin{array}{l}\text { Modulus } \\
\left(\mathrm{N} / \mathrm{mm}^{2}\right)\end{array}$ & $\begin{array}{l}\text { Modulus } \\
@ \quad 0.000 \\
\mathrm{~N} / \mathrm{mm}^{2} \\
\left(\mathrm{~N} / \mathrm{mm}^{2}\right)\end{array}$ & $\begin{array}{l}\text { lus } 0.000 \text { to } \\
0.000 \mathrm{~N} / \mathrm{mm}^{2} \\
\left(\mathrm{~N} / \mathrm{mm}^{2}\right)\end{array}$ \\
\hline 1 & 7.753 & 2.710 & 26.133 & 25.187 & 174.476 & 4.727 & \\
\hline
\end{tabular}

flection (mm) for the $255 \mathrm{~g}, 265 \mathrm{~g}$ and $275 \mathrm{~g}$ fire blocks of clay composites respectively. Figure 9 compares the behaviours of the three fire blocks together. The plot reveals the maximum load of the fire blocks at respective deflection $(\mathrm{mm})$. Our interest in these plots is to investigate and compares the maximum load fire block clays composites can withstand. The $275 \mathrm{~g}$ block has the maximum compressive strength and Young Modulus of $7652 \mathrm{~N}$ and $212 \mathrm{~N} / \mathrm{mm}^{2}$ respectively making it better than the $255 \mathrm{~g}$ and $265 \mathrm{~g}$ blocks for furnace lining application. 
Table 4. Compressibility Analysis of $265 \mathrm{~g}$ Block of Clay

\begin{tabular}{|c|c|c|c|c|c|c|c|}
\hline $\begin{array}{l}\text { Test } \\
\text { No }\end{array}$ & $\begin{array}{l}\text { Def. @ } \\
\text { Break } \\
(\mathrm{mm})\end{array}$ & $\begin{array}{l}\text { Def. @ } \\
\text { L.O.P. } \\
(\mathrm{mm})\end{array}$ & $\begin{array}{l}\text { Def. @ } \\
\text { Peak } \\
(\mathrm{mm})\end{array}$ & $\begin{array}{l}\text { Def. } \\
@ \\
\text { Yield } \\
(\mathrm{mm})\end{array}$ & $\begin{array}{l}\text { Force @ } \\
\text { Break } \\
(\mathrm{N})\end{array}$ & $\begin{array}{l}\text { Force @ L.O.P. } \\
(\mathrm{N})\end{array}$ & Force @ Peak (N) \\
\hline 1 & 4.671 & 2.164 & 3.628 & 2.273 & 1438.900 & 847.400 & 3851.000 \\
\hline $\begin{array}{l}\text { Test } \\
\text { No }\end{array}$ & $\begin{array}{l}\text { Force } \\
\text { @ Yield } \\
(\mathrm{N})\end{array}$ & $\begin{array}{l}\text { Strain@ } \\
\text { Break } \\
(\%)\end{array}$ & $\begin{array}{l}\text { Strain@ } \\
\text { L.O.P. } \\
(\%)\end{array}$ & $\begin{array}{l}\text { Strain } \\
@ \\
\text { Peak } \\
(\%)\end{array}$ & $\begin{array}{l}\text { Strain } \\
\text { @ Yield } \\
(\%)\end{array}$ & $\begin{array}{l}\text { Stress@ @ Break } \\
\left(\mathrm{N} / \mathrm{mm}^{2}\right)\end{array}$ & $\begin{array}{l}\text { Stress @ L.O.P. } \\
\left(\mathrm{N} / \mathrm{mm}^{2}\right)\end{array}$ \\
\hline 1 & 1038.600 & 8.493 & 3.935 & 6.596 & 4.133 & 1.022 & 0.602 \\
\hline $\begin{array}{l}\text { Test } \\
\text { No }\end{array}$ & $\begin{array}{l}\text { Stress } \\
\text { @ Peak } \\
\left(\mathrm{N} / \mathrm{mm}^{2}\right)\end{array}$ & $\begin{array}{l}\text { Stress } \\
\text { @ Yield } \\
\left(\mathrm{N} / \mathrm{mm}^{2}\right)\end{array}$ & $\begin{array}{l}\text { Time to } \\
\text { Failure } \\
\text { (Secs) }\end{array}$ & $\begin{array}{l}\text { Time } \\
\text { to } \\
\text { Peak } \\
(\text { Secs }) \\
\end{array}$ & $\begin{array}{l}\text { Youngs } \\
\text { Modulus } \\
\left(\mathrm{N} / \mathrm{mm}^{2}\right)\end{array}$ & $\begin{array}{l}\text { Tangential } \\
\text { Modulus @ } \\
0.000 \quad \mathrm{~N} / \mathrm{mm}^{2} \\
\left(\mathrm{~N} / \mathrm{mm}^{2}\right)\end{array}$ & $\begin{array}{l}\text { Secant Modulus } \\
0.000 \text { to } 0.000 \\
\mathrm{~N} / \mathrm{mm}^{2}\left(\mathrm{~N} / \mathrm{mm}^{2}\right)\end{array}$ \\
\hline 1 & 2.735 & 0.738 & 28.100 & 21.845 & 93.892 & 21.094 & \\
\hline
\end{tabular}

Table 5. Compressibility Analysis of $275 \mathrm{~g}$ Block of Clay

\begin{tabular}{|c|c|c|c|c|c|c|c|}
\hline $\begin{array}{l}\text { Test } \\
\text { No }\end{array}$ & $\begin{array}{l}\text { Def. @ } \\
\text { Break } \\
(\mathrm{mm})\end{array}$ & $\begin{array}{l}\text { Def. @ } \\
\text { L.O.P. } \\
(\mathrm{mm})\end{array}$ & $\begin{array}{l}\text { Def. @ } \\
\text { Peak } \\
(\mathrm{mm})\end{array}$ & $\begin{array}{l}\text { Def. @ } \\
\text { Yield } \\
(\mathrm{mm})\end{array}$ & $\begin{array}{l}\text { Force @ } \\
\text { Break } \\
(\mathrm{N})\end{array}$ & $\begin{array}{l}\text { Force @ @ } \\
\text { L.O.P. (N) }\end{array}$ & Force @ Peak (N) \\
\hline 1 & 3.734 & 2.349 & 3.132 & 3.132 & 7652.000 & 2964.300 & 9658.000 \\
\hline $\begin{array}{l}\text { Test } \\
\text { No }\end{array}$ & $\begin{array}{l}\text { Force } \\
\text { @ Yield } \\
(\mathrm{N})\end{array}$ & $\begin{array}{l}\text { Strain@ } \\
\text { Break } \\
(\%)\end{array}$ & $\begin{array}{l}\text { Strain@ } \\
\text { L.O.P. } \\
(\%)\end{array}$ & $\begin{array}{l}\text { Strain } \\
@ \text { Peak } \\
(\%)\end{array}$ & $\begin{array}{l}\text { Strain } \\
@ \text { Yield } \\
(\%)\end{array}$ & $\begin{array}{l}\text { Stress } \\
@ \quad \text { Break } \\
\left(\mathrm{N} / \mathrm{mm}^{2}\right)\end{array}$ & $\begin{array}{l}\text { Stress @ L.O.P. } \\
\left(\mathrm{N} / \mathrm{mm}^{2}\right)\end{array}$ \\
\hline 1 & 9658.000 & 6.789 & 4.271 & 5.695 & 5.695 & 4.270 & 1.654 \\
\hline $\begin{array}{l}\text { Test } \\
\text { No }\end{array}$ & \begin{tabular}{l}
\multicolumn{2}{l}{ Stress } \\
$@$ Peak \\
$\left(\mathrm{N} / \mathrm{mm}^{2}\right)$
\end{tabular} & $\begin{array}{l}\text { Stress } \\
\text { @ Yield } \\
\left(\mathrm{N} / \mathrm{mm}^{2}\right)\end{array}$ & $\begin{array}{l}\text { Time to } \\
\text { Failure } \\
\text { (Secs) }\end{array}$ & $\begin{array}{l}\text { Time } \\
\text { to Peak } \\
\text { (Secs) }\end{array}$ & $\begin{array}{l}\text { Youngs } \\
\text { Modulus } \\
\left(\mathrm{N} / \mathrm{mm}^{2}\right)\end{array}$ & $\begin{array}{l}\text { Tangential } \\
\text { Modulus } \\
@ \quad 0.000 \\
\mathrm{~N} / \mathrm{mm}^{2} \\
\left(\mathrm{~N} / \mathrm{mm}^{2}\right)\end{array}$ & $\begin{array}{l}\text { Secant Modulus } \\
0.000 \text { to } 0.000 \\
\mathrm{~N} / \mathrm{mm}^{2}\left(\mathrm{~N} / \mathrm{mm}^{2}\right)\end{array}$ \\
\hline 1 & 5.390 & 5.390 & 22.443 & 18.842 & 212.102 & 6.752 & \\
\hline
\end{tabular}

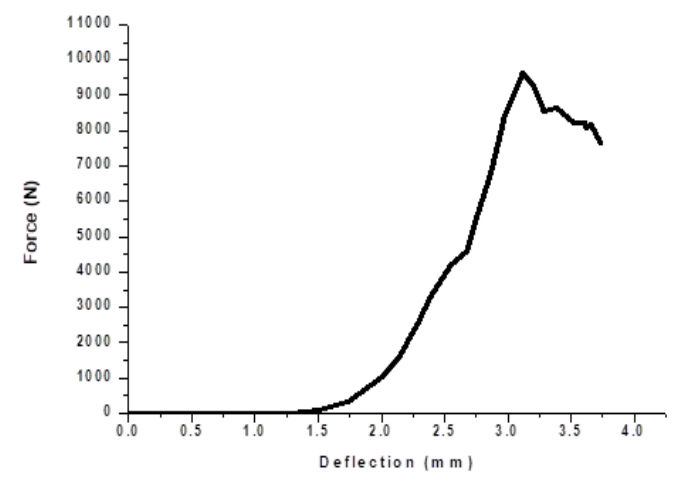

Figure 8 . Force $(\mathrm{N})$ against Deflection $(\mathrm{mm})$ of: $275 \mathrm{~g}$ fine and coarse fire block of clay composites

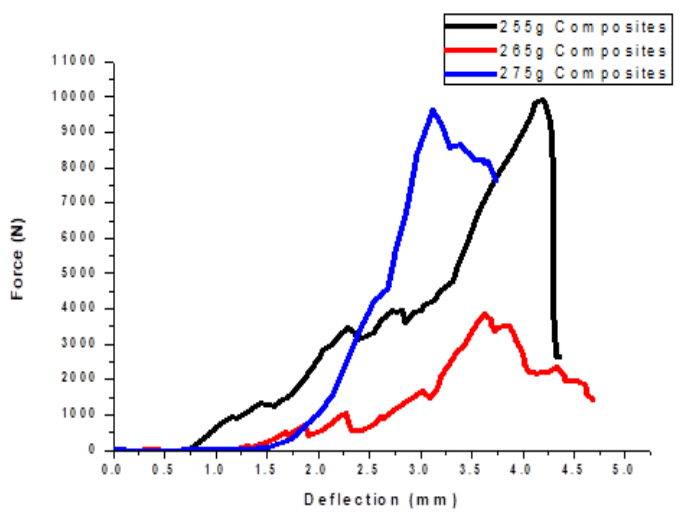

Figure 9. Force $(\mathrm{N})$ against Deflection $(\mathrm{mm})$ of different fabricated fine and coarse fire blocks of clay composites 


\section{Conclusion}

In this research work, Okelele fine and coarse clays have been characterized to establish their potentials for furnace lining application. The maximum compressive strength and Young Modulus as demonstrated by $275 \mathrm{~g}$ block clay are $7652 \mathrm{~N}$ and $212 \mathrm{~N} / \mathrm{mm}^{2}$ at firing temperature of $1200{ }^{\circ} \mathrm{C}$. The results of compressive strength analysis, mineral phase's identification and ability to withstand higher firing temperature of $1200^{\circ} \mathrm{C}$ proved that, Okelele fine and coarse fire block of clays meet the needed criteria for use as refractory raw materials.

\section{References}

[1] J. B. Mokwa, S. A. Lawal, M. S. Abolarin \& K. C. Bala,"Characterization And Evaluation Of Selected Kaolin Clay Deposits In Nigeria For Furnace Lining Application", Nigerian Journal of Technology (NIJOTECH), 38 (2019) 936.

[2] J. A. Amkpa; A. E. Aye \& F. E. Omagu, "Mechanical and Physicochemical Evaluation of Alkaleri Fireclay for Refractory Application", Traektoriâ Nauki = Path of Science 3 (2017).

[3] A. M. Yami; M. A. B. Hassan \& S. Umaru, "Evaluation of the Refractory Characteristics of Dukku Clay Deposit", Continental J. Engineering Sciences 2 (2007) 15.

[4] P. U. Ochieze, \& D. E. Esezobor, "Performance Evaluation of Refractory Bricks Produced from Nigerian Fireclays Blended with Zircon”, Global Journal of Researches in Engineering: J. General Engineering 18 (2018) 1.

[5] P. O. Aiyedun, O. S. Olokode, S. O. Fakolujo, \& B. U. Anyanwu, "An Evaluation of Strength Characteristics of Osiele Clay", The Pacific Journal of Science and Technology, 13 (2012).
[6] Z. Elakhame, S. A. Bello, J. O. Agunsoye, I. Patric \& O. Otitoju, "Characterization of Ujogba Clay Deposits in Edo State, Nigeria for Refractory Applications, Journal of Science", Engineering and Technology, Kathmandu University (2016) 1271.

[7] A. B. Etukudoh; K. G. Akpomie \& O. C. B. Okereke, "Characterization of Ezzodo clay deposit for its industrial potentials", International Journal of Advanced Engineering Research and Technology (IJAERT) 4 (2016) 1.

[8] S. P. Malu, J. T. Ugye \& R. B. Donatus, "Characterization of Clay for Industrial Application By Physicochemical, Xrf, And Tga Methods", FUW Trends in Science \& Technology Journal 3 (2018) 314.

[9] E. E. Nnuka \& J. O. Adekwu, "Refractory Characteristics of Kwa Clay Deposit in Plateau State", N.S.E, Technical Transaction 32 (1998) 54.

[10] O. Ombaka, "Characterization and classification of clay minerals for potential applications in Rugi Ward, Kenya", African Journal of Environmental Science and Technology 10 (2016) 415.

[11] J. O. Osarenmwinda, "Fabrication and performance evaluation of oilfired crucible furnace using locally sourced materials", Int. Journal of Engineering Research and Applications 5 (2015) 29.

[12] I. F. Titiladunayo \& O. P. Fapetu, "Selection of Appropriate Clay for Furnace Lining In a Pyrolysis Process", Journal of Emerging Trends in Engineering and Applied Sciences (JETEAS) 2 (2011) 938.

[13] J. C. Ugwuoke \& N.I. Amalu, "Characterization of Obe Clay Deposits for Refractory Production", American Journal of Engineering Research (AJER) 6 (2017) 74.

[14] A. B. Alabi; M. A. Salawu; R. A. Jimoh \& T. Akomolafe, Appraisal of mechanical properties of different particle sizes of palm kernel shell, coconut shell and mixed palm kernel-coconut shells particles epoxy-filled composites, Sri Lankan Journal of Physics 21 (2020) 1.

[15] O. J. Omowumi, Characterization of Some Nigerian Clays as Refractory Materials for Furnace Lining, Nigerian Journal of Engineering Management 2 (2000) 1 .

[16] E. E. Nnuka \& Agbo J. E, Evaluation of the Refractory Characteristics of Otukpo Clay Deposit, N.S.E, Technical Transaction 35 (2000) 32. 